\title{
The Few, the Proud, the Profs
}

\section{Mark Bauerlein}

If you came through graduate school in the 1980s in a humanities field and wanted to impress your professors, hiring committees, and peer reviewers at presses and journals, the trait you most coveted was intelligence. If you were applying for a tenure-track job and on a campus visit delivered a talk to the faculty that was derived from your dissertation, the conclusion you most wanted each member of the audience to draw was, "Yeah, he's really smart." Even better: "That was brilliant."

Raw brain power-that was the top virtue, not erudition, scholarly mien, deliberative reasoning, or even political correctness. Most of the professors were left-liberal with a few flirtations with radicalism. But when it came to who gets the post, they acted predominantly like aristocrats of IQ. Jobs were scarce, competition was avid, and survivors who landed a position had good reason to judge themselves a deserving elite. They were the smartest people in the room.

Of course, the smarts they valued were, in truth, narrower than $g$, that fluid cognitive talent that everyone possesses to greater and lesser degrees. "Intelligence" in the humanities in 1990 meant more than anything else a sophisticated, informed handling of theory in its various forms (deconstruction, Foucault, Lacanian and feminist psychoanalysis, New Historicism, raceclass-gender theory). Do you show sufficient understanding of Grammatology and Discipline and Punish? Were you up-to-speed on the latest trends in Queer Studies? This is what made you smart. If you didn't meet that first criterion, people couldn't trust you to join the department, become department chairman,

\footnotetext{
Mark Bauerlein is professor emeritus of English at Emory University, Atlanta, GA 30322; engmb@emory. edu. He is a contributing editor of First Things and from 2003 to 2005 served as director of the Office of Research and Analysis at the National Endowment for the Arts. His latest books are The State of the American Mind: 16 Leading Critics on the New Anti-Intellectualism, co-edited with Adam Bellow (Templeton, 2015), and The Digital Divide: Arguments for and Against Facebook, Google, Texting, and the Age of Social Networking (Jeremy P. Tarcher, 2011). Bauerlein last appeared in these pages with his review "The Rediscovery of Curriculum," in spring 2020.
} 
or rise to the deanship. Only the very sharpest minds entered the ranks and became leaders.

Thirty years have passed, and the individuals marked as brilliant back then have, indeed, taken charge of the disciplines. They have run departments and edited journals, hosted conferences and reviewed publications, approved grants and monitored admissions and hiring. Judith Butler, for example, recently served as president of the Modern Language Association. Who else should run things? Only those who thrived in the academy because they were so sharp, enjoying productive careers and prosperous lives while steering the humanities into new directions every ten years or so. Winning awards, attracting graduate students, and delivering keynote lectures every year, how could they not believe that they were the right people to manage the institutions?

It only takes a simple question for the whole assumption to crash to the ground: How have the institutions they led fared? They were captains of the humanities-let's do a quick performance review.

Lots of data are compiled by the Humanities Indicators, a project of the American Academy of Arts and Sciences which shows clearly the falling trend. It finds that English, history, foreign languages, linguistics, classics, and philosophy in the early-90s, when the smartest minds in the room were coming to power, collected nearly nine percent of all bachelor's degrees. By 2015, the rate had fallen to 5.4 percent. Here was the headline of a January 2019 story in the Chronicle of Higher Education: “Colleges Lose a 'Stunning' 651 ForeignLanguage Programs in 3 years.”

The jobs numbers look just as bad. In 2018, the Modern Language Association reported a decline in the number of slots advertised in the MLA Job List for the sixth year in a row. This year, the best that history could say was that the decline in 2020 was a bit smaller than previous years, indicating perhaps that the long-term fall could be slowing down and leveling off. For art history, a July 2020 story in artnetnews.com summarized, "academic jobs in particular have long been declining in terms of wages, job security, and benefits." It quotes an art historian at University of Chicago saying, “The number of tenure-track faculty jobs has decreased dramatically and have been replaced with adjuncts or lecturers who have one or two classes, but don't have the job security or intellectual freedom that tenure offers."

These are just a few markers, but we don't have to be comprehensive to make the point. Everything is down-majors, jobs, number of programs, sales 
of monographs, and citation of journal articles. If the humanities were a private corporation, the leadership would have been fired long ago. Such incompetence wouldn't be tolerated. Blame would be assigned and guilty parties released. But in the humanities the smartest people in the room seem unaware of their own dereliction. They have witnessed the thinning out of their fields, but haven't registered any responsibility for it. They continue to do their own thing even as the status of their departments diminishes each semester.

The problem goes back precisely to the dominance of smarts in the heydays of theory. Back then, in the evaluation of young humanists, a person's institutional conscience didn't come into play. Nobody on a hiring committee asked an interviewee, "What do you think is the best way to maintain a steady flow of sophomores into the major?" That was too pedestrian a question for the gifted minds around the table to entertain. Nobody told young professors, "You must keep in mind what the general public wants out of our graduates-that's what will keep us strong." Nobody paused to wonder whether Intersectionality would enhance or damage the reputation of English. No, they were too busy being brilliant to be sensible and managerial.

Has there ever been a professional group so intellectually developed in one regard and operationally stultified in another? These are people who can analyze a complex poem into little pieces and weave an intricate web of meaning around and through them, but they are incapable of persuading outsiders of the value of their activity. They apply a razor-sharp scrutiny of their peers when deciding who gets hired and promoted and published and awarded, but they have no sense of how unappealing they are to laypersons. Oh, the public appreciates a knowledge of Shakespeare, and businesses love to hire grads who read well and write clearly, but a teacher who produces such students hasn't demonstrated the brilliance his colleagues currently prize. Professors are impressed, instead, by astute socio-political identitarian interpretations, not by sparkling lectures at the public library on Jane Austen, or even by a teacher who draws large enrollments in a sophomore survey class.

Worst of all, the topmost figures have little inclination to examine themselves in this age of decline. They will complain of careerism among the students, of conservative leaders attacking the humanities, the general antiintellectualism of American society, the university push for STEM (it brings in Federal dollars), and a corporate mentality in the administration building, but they won't look at themselves. They learned early on to disengage from 
institutions and individualize their work. What happens to the university at large and to the discipline at large has only a small bearing upon what they do, or so they believe.

When I worked at the National Endowment for the Arts under Dana Gioia (2003-05), he insisted that his directors review themselves each year. I'm not sure if he formalized the process for everyone, but he told me once that I should do so, adding that the important thing was not to gather my team in the research office and determine what we did right. It was the opposite: What did we do wrong? It was a refreshing angle, a relief, in fact. In my many years in academia up until then, I found that professors rarely admitted that they did something wrong. If they misconceived a project, mishandled a student, voted incorrectly in a meeting, or said the wrong thing, well, they let it go. It was too embarrassing to discuss. People might conclude that you weren't as smart as they thought you were, and that could be crushing.

But, of course, we made mistakes all the time. I was the Director of Undergraduate Studies in English for several years and stumbled once a week. The chairman at the time was a genial fellow and we had good rapport, so I could tell him of the occasional misstep and he would work around it. But I wouldn't want the whole department in a faculty meeting to hear about my errors. In reporting on undergraduate affairs, I stuck to nuts and bolts and numerical successes such as enrollment figures, which were quite high back then. How much more pleasant it would have been, though, to be able to bring mistakes to everybody and see them approach problems not in a mood of judgment but of group repair. I loved working for Gioia.

The humanities won't move in that direction, though. The job market isn't going to improve, and the Woke Revolution has only made everyone more insecure. Besides, it could, indeed, be true that the humanities have hit bottom. They are now a minor part of the university and will stay that way, neither rising much nor falling much. The damage has been done, the professors have remained in place, and the fields limp along from year to year. Those figures of brilliance are now in their 60s, riding out the last days of tenure. They have overseen the remarkable collapse of an institution that in 1980 was at the center of the campus and is now at the margins. Why assume responsibility for something for which they never felt responsible before? Why bring the wrong attention to yourself? It is impossible for an academic who's been told all his life how smart he is to admit that in a very important way he was very dumb. 